\title{
The role of the school in preparing students to lead a healthy lifestyle
}

\author{
Danuta Umiastowska ${ }^{1}$, Lila Kopeć-Pławińska ${ }^{2}$ \\ 1 University of Szczecin, Institute of Physical Culture Sciences; danuta.umiastowska@usz.edu.pl \\ 2 Vocational School Complex No. 3 in Szczecin; lila-skok@o2.pl \\ * danuta.umiastowska@usz.edu.pl
}

\begin{abstract}
Preparation of students for adult life also includes the area of health care. Health education is part of the core curriculum of Polish schools. The leading role of the health educator is assumed by the physical education teacher, but many other educational tasks are carried out by all school staff. The present study attempts to answer the question: How is health education implemented at school? The research project was carried out among students of various colleges in the city of Szczecin in Poland. At the same time, similar studies were conducted among students from other university in other cities. The research method was a diagnostic survey, with the main assessment tool being the 'Questionnaire for Assessment of Implementation of Physical Education at Secondary School' by Krystyna Górna-Łukasik from the Jerzy Kukuczka Academy of Physical Education in Katowice. On the basis of the study results, an attempt was made to determine the forms and methods of work and the involvement of various types of teachers in health education. The statistical analysis sought correlations between the students' opinions about the ways in which the curriculum content was implemented, university majors, and PE teachers' sex.
\end{abstract}

Keywords: health education, secondary school, physical education teacher

\section{Introduction}

Education and upbringing play an important role in preparing a person for adult life, in particular, to fulfill various social roles. They also affect the formation of desirable social attitudes, including care for one's own and other people's health, the quality of one's own life, society and the environment, which manifest themselves in the display of specific behaviors. Health is the supreme value conditioning human functioning. According to the World Health Organization health is a state of complete physical, mental and social wellbeing and not merely the absence of disease or infirmity. Health should also be considered in four aspects:

- physical - the proper functioning of the human body;

- mental - maintaining internal balance and coping with stress;

- social - the ability to establish social contacts and functions in the family, school, and professional environment;

- spiritual - the ability to act in accordance with the accepted system of values [1-7].

According to B. Woynarowska, health education is a long-term process in which children and adolescents gain the knowledge related to health and the ways of maintaining and improving it. They also acquire habits and skills that are conducive to creating the right conditions for health and to coping with conditions of illness or disability [1]. On the one hand, health education provides school students with the awareness about healthand life-threatening factors, and on the other hand, with the knowledge about increasing health potential, including the principles of healthy lifestyle and coping with new situations [6, 8-11]. It is also important to emphasize the practical aspect of health education activities aimed at 'the development of practical skills to apply knowledge in everyday life situations' $[12$, p.40]. According to the ministerial regulation on the core curriculum in 
Polish schools, 'health education, (...) carried out consistently and competently, will contribute to the improvement of the health condition of the society and the economic prosperity of the country' [13, p. 311].

Health perception is the subjective process of understanding how the human body functions in health and in disease [14-16].

Health education has been included in the core curriculum of general education at all stages of schooling: from kindergarten, through elementary schools, to different types of secondary schools $[13,17]$.

Conducting school health education classes contributes to the achievement of objectives of the core curriculum for general education through which students get to know themselves, diagnose health problems, in particular, in relation to counteracting the diseases of civilization, learn responsibility for their own and others' health, improve personal and social competencies, strengthen self-esteem, be able to function in everyday life and create an environment conducive to maintaining good health [6, 18-22]. These objectives are implemented in two ways:

- 'subject-oriented - with a clear emphasis on the leading role of physical education (teaching and learning about health within the framework of health education) and the inclusion of health education in the curricula of various subjects;

- educational and preventive - stressing the axiological dimension (values of health and healthy lifestyle included in the educational programs of disease prevention) [6, p.19].

Health education in the new secondary school core curriculum has been included in the educational contents of a number of school subjects, such as biology, foundations of entrepreneurship, modern foreign languages, and geography. However, only in physical education has the component of 'Health Education' been identified together with the specific requirements grouped in four sections: physical development, physical activity, safety in physical activity, and social competence. Importantly, the themes proposed by the legislators in the above sections are also conducive to attaining health education goals. For example, in the area of physical development, the student will acquire the knowledge about the relationship between physical fitness, health and well-being, and will be able to evaluate his/her own body's reactions to physical exercise of different intensities; in the area of physical activity, the student will know selected relaxation techniques and organizes his/her own weekly physical activity (health training) with respect to health recommendations (e.g. WHO or EU); in terms of safety in physical activity the student will be able to assess the risk of injury associated with some sports and to behave in an emergency situation; finally, in terms of social competence the student will act as an organizer, competitor, judge and supporter in sports competitions and recreational events and will take individual and team initiatives.

Teachers of all subjects, school counsellors, support teachers and school psychologists as well as non-teaching staff, who are an integral part of the school environment, are also responsible for the implementation of the health education content at school. However, the most important role is attributed to the teachers of biology, family life education and physical education. The last - according to many researchers [6, 23-25] - have a special role in attaining the goals of health education due to their substantive preparation and organizational conditions that allow them to make use of various activation methods and conduct classes in an unconventional way. The role of PE teachers - due to the focus of modern education on 'learning' rather than 'teaching' - has undergone an evolution. Nowadays a PE teacher acts primarily as a guide, leader, advisor, animator, and model of appropriate pro-health attitudes [26]. In his/her actions a PE teacher should be open to the needs of students, show respect and understanding, undertake joint actions with both students and their parents and guardians, other teachers and specialists, contribute to the formation of the educational environment, and create situations conducive to the achievement of health education goals (Szpak, 2020). According to M. Ostrowska: 'Authenticity, empathy and acceptance in teacher-student relations create a bridge between upbringing and teaching. Through such targeted educational interactions, we help the students find meaning and values in life, and at the same time, we build the right foundation for the 
formation of their life skills' [24, p.73]. A physical education teacher, who is also a leader or promoter of health at school, must have the appropriate professional background to optimally implement the contents of health education. For this purpose, it is necessary for PE teachers to have competencies that can be divided into:

- scientific - related to their level of knowledge, e.g. about health, functioning of the human body, lifestyle diseases, stress, threatening influences, etc.;

- pedagogical - which enable the selection of appropriate methods, forms and didactic means for the implementation of specific content and the fulfillment of students' expectations and abilities;

- $\quad$ social - that affect the development of relationships, creating an atmosphere conducive to the acquisition of skills and the formation of desirable habits;

- organisational - which determine the creation of a material environment and space for educational activities.

Some researchers identify only subject-related competences and pedagogical competences [27], while others specify them in more detail. K. Wojciechowska further divides the competences into creative, information and media, moral, diagnostic, cooperation, technical or emotional, among others [28].

Effective conduct of the educational process in the field of health education should be realized on the basis of a reliable diagnosis of the possibilities, needs and expectations of students; the use of various forms of teaching to motivate and make classes more attractive; the involvement of students in the creation and implementation of class themes; combining information from different sources; presenting models of health behavior with respect to authorities, and organizing conditions for practical activities [6, 18, 29-30].

Issues of health education are introduced as part of physical education classes, extracurricular activities and projects included in the school educational and disease prevention program. In addition - according to the provisions of the core curriculum - the school should create conditions for independent inquiry, problem solving, cooperation, and development of key competencies. This provides teachers with an opportunity to utilize a variety of methods and forms of work with students. Specialists in pedagogy, didactics and education propose to implement - in addition to traditional methods such as lectures, talks, working with texts - various activation methods. B. Woynarowska highlights the significance of such methods as discussion, role plays, portfolios, projects, and visualization. Particular importance is also attached to those ways and forms of student participation in the implementation of health education content, which contain elements of fun, competition, and opportunities to test oneself in practical activities, e.g. sports and recreation festivals (events), quizzes, knowledge competitions, etc. [18].

It is important to note that the quality of provided health education depends not only on the scope of knowledge, teaching, or organizational skills. The effects on interactions and, consequently, on the formation of pro-health attitudes of students also rely on the personality of the health leader, his/her empathy, authenticity and thoroughness in the implementation of tasks, and traits and skills which, unfortunately, the future teacher cannot be equipped in during professional teaching training [24]. The effects on the achievement of the assumed goals of health education are conditioned by the functioning and cooperation of all participants in the school environment, namely, the school management, teaching and non-teaching staff, students and their parents, as well as institutions supporting various school activities.

K. Borzucka-Sitkiewicz in her survey among health promotion coordinators in institutions participating in the network of Health Promoting Schools, concerning ways of health education implementation, found that more than $86 \%$ of respondents reported the implementation of health education within various school courses. Every tenth respondent $(12 \%)$ admitted that a distinct course had been created to achieve the goals of the program. Among the forms used to convey the health content, teachers mad use of school projects, ad hoc events, outdoor trips as well as lectures by outside experts [31]. K. Łomińska in her survey of teachers of Warsaw schools, found that health education was implemented by physical education specialists, conducting classes in the gym (70.8\%), 
and less frequently in regular classrooms (55.6\%) [32]. P.F. Nowak, in a study on the population of teachers in Opole regarding the level of implementation of health education at school, found out that in most institutions various types of pro-health activities had been carried out [33]. M. Zadarko-Domaradzka in her evaluation of health education implementation, based on the opinions of teachers in Opole reported that physical education teachers were the most qualified to teach this subject [34].

Research on students' perception of health education was conducted by $M$. Charzyńska-Gula et al., K. Kap et al., A. Bednarek and E. Chmielewska, A. Szkudlarek et al. and S. Świtała and K. Bukowska. In their study health education themes were found to have been provided in the form of lessons prepared by students, using activating methods, including genre scenes as workshop activities [35], such as first aid, or problem solving in small groups [36]. Sources of health knowledge are most often physical education (35.5\%) and biology classes (29.4\%), with health information also provided in chemistry classes, civil defense courses, and homerooms [37]. According to Warsaw students, classes should be taught by educated specialists in this area $(26 \%)$ or specialists from outside the school (45\%) [35]. The vast majority of female students from Łódź (70\%) confirmed the need for health education classes, and $2 / 3$ of male students $(62 \%)$ said they were unnecessary [38]. A similar opinion was collected among female students in Wrocław, who acknowledged that the content implemented in the form of classroom activities was interesting and relevant to their development. Introducing theoretical classes into physical education classes does not - in their opinion - lower the quality of physical activity [39]..

\section{Materials and Methods}

The present study was conducted as part of a joint research project at the University of Szczecin and the Jerzy Kukuczka Academy of Physical Education in Katowice. A diagnostic survey was conducted among 303 students of the University of Szczecin (194 women and 109 men). The research tool used was the 'Questionnaire for Assessment of Implementation of Physical Education in Secondary Schools' designed by Krystyna Górna-Łukasik. The project was approved by the relevant Bioethics Committee (No. KBI43/17). The reliability assessed with the Spearman-Brown formula and Cronbach's alpha was in the range between 0.86 and 0.96 [40]. Corresponding to the research questions, 12 statements were selected for statistical analysis. They were all rated on a five-point Likert scale ( 1 point - no occurrence of a given form, 5 points - frequent occurrence of a given form). The comparison of results was made for all students, separately for men and women, and for students of physical education and students of other majors. Statistical analysis was performed using IBM SPSS Statistics v. 25. Due to the ordinal nature of the collected data and the non-equinumerosity of the compared groups, non-parametric tests were applied: the Mann-Whitney $U$ test for two independent groups, and the KruskalWallis $\mathrm{H}$ test for three independent groups. In tables, descriptive statistics were presented as means (M) and standard deviation (SD) to increase the visibility of differences between groups. The level of statistical significance was set at $\mathrm{p}<0.05$.

\section{Results}

The most common forms of promoting a healthy lifestyle were sports and recreational events (Statement 8). The least frequent form of promoting healthy lifestyles were lectures for parents (Statement 3). The male students more often declared that in their schools lectures on healthy lifestyle had been given by teachers, outside classes for students and parents, teachers of theoretical subjects provided active recreation during classes (e.g. respiratory exercises, in-class physical exercises), and that teachers corrected body posture and emphasized the principles of a healthy lifestyle (Table 1). These opinions were statistically significant.

Table 1. Opinions of all students on the implementation of health education content in their schools. 


\begin{tabular}{|c|c|c|c|c|c|c|}
\hline \multirow{2}{*}{$\begin{array}{l}\text { Implementation } \\
\text { of health educa- } \\
\text { tion content }\end{array}$} & \multicolumn{2}{|c|}{ Women, $\mathrm{n}=194$} & \multicolumn{2}{|c|}{ Men, $n=109$} & \multicolumn{2}{|c|}{$\begin{array}{c}\text { Manna-Whitneya } \\
\text { U Test }\end{array}$} \\
\hline & M & SD & M & SD & $\mathrm{Z}$ & $\mathrm{p}$ \\
\hline Statement 1 & 2,21 & 1,30 & 2,16 & 1,29 & $-0,323$ & 0,747 \\
\hline Statement 2 & 1,66 & 1,12 & 1,97 & 1,19 & $-2,768$ & 0,006 \\
\hline Statement 3 & 1,24 & 0,67 & 1,46 & 0,95 & $-2,069$ & 0,039 \\
\hline Statement 4 & 3,03 & 1,22 & 2,85 & 1,39 & $-1,156$ & 0,248 \\
\hline Statement 5 & 1,64 & 1,10 & 2,01 & 1,36 & $-2,108$ & 0,035 \\
\hline Statement 6 & 3,24 & 1,45 & 3,27 & 1,34 & $-0,027$ & 0,978 \\
\hline Statement 7 & 1,79 & 1,07 & 2,20 & 1,30 & $-2,731$ & 0,006 \\
\hline Statement 8 & 3,87 & 1,09 & 3,98 & 1,06 & $-0,907$ & 0,364 \\
\hline Statement 9 & 2,36 & 1,25 & 2,62 & 1,19 & $-2,114$ & 0,034 \\
\hline Statement 10 & 2,71 & 1,32 & 2,91 & 1,33 & $-1,326$ & 0,185 \\
\hline Statement 11 & 2,70 & 1,37 & 2,98 & 1,35 & $-1,785$ & 0,074 \\
\hline Statement 12 & 3,04 & 1,30 & 2,81 & 1,42 & $-1,522$ & 0,128 \\
\hline Total & 29,50 & 9,04 & 31,22 & 10,55 & $-1,174$ & 0,240 \\
\hline
\end{tabular}

Legend: Statement 1: Talks on health for students by outside experts; Statement 2: Talks on health for students by teachers outside PE lessons; Statement 3: Talks on health for parents; Statement 4: Teachers of other subjects than PE convinced students of the need for a healthy lifestyle; Statement 5: Teachers of other subjects than PE provided students with active recreation during lessons; Statement 6: Sports and recreational events were organized at school for students, teachers and parents; Statement 7: Teachers corrected students' body posture; Statement 8: There was a student-friendly atmosphere at school, Statement 9: The school paid attention to the principles of healthy lifestyles; Statement 10: The school provided opportunities for students to use extracurricular sources of information about health; Statement 11: Teachers organized extracurricular activities and events to promote healthy lifestyles; Statement 12: Competitions and exhibitions on health-related topics were organized at school. M - mean; SD - standard deviation; Z - Mann-Whitney U test, p - level of statistical significance

Source: author's own research

Table 2 presents the opinions of physical education university students about the ways health education had been implemented in their secondary school. There were no significant statistical differences between male and female students' opinions. 
Table 2. Physical education students' opinions on the provision of health education contents at school.

\begin{tabular}{ccccccc}
\hline $\begin{array}{c}\text { Implementation } \\
\text { of health educa- } \\
\text { tion content }\end{array}$ & \multicolumn{2}{c}{ Women, $\mathrm{n}=74$} & \multicolumn{2}{c}{ Men, $\mathrm{n}=70$} & \multicolumn{3}{c}{$\begin{array}{c}\text { Manna-Whitneya } \\
\text { U Test }\end{array}$} \\
\cline { 2 - 7 } & $\mathrm{M}$ & $\mathrm{SD}$ & $\mathrm{M}$ & $\mathrm{SD}$ & $\mathrm{Z}$ & $\mathrm{p}$ \\
\hline Statement 1 & 2,26 & 1,33 & 2,13 & 1,30 & $-0,598$ & 0,550 \\
Statement 2 & 1,84 & 1,22 & 1,91 & 1,11 & $-0,751$ & 0,453 \\
Statement 3 & 1,23 & 0,65 & 1,46 & 0,99 & $-1,205$ & 0,228 \\
Statement 4 & 3,09 & 1,15 & 2,93 & 1,44 & $-0,726$ & 0,468 \\
Statement 5 & 1,64 & 1,14 & 1,90 & 1,31 & $-1,268$ & 0,205 \\
Statement 6 & 3,53 & 1,41 & 3,31 & 1,29 & $-1,090$ & 0,276 \\
Statement 7 & 1,92 & 1,12 & 2,07 & 1,31 & $-0,456$ & 0,648 \\
Statement 8 & 3,89 & 1,03 & 4,01 & 1,01 & $-0,798$ & 0,425 \\
Statement 9 & 2,51 & 1,23 & 2,66 & 1,09 & $-1,006$ & 0,315 \\
Statement 10 & 2,68 & 1,30 & 2,89 & 1,14 & $-1,018$ & 0,309 \\
Statement 11 & 2,66 & 1,40 & 2,84 & 1,28 & $-0,932$ & 0,352 \\
Statement 12 & 3,08 & 1,31 & 2,80 & 1,35 & $-1,258$ & 0,208 \\
\hline Total & 30,32 & 9,36 & 30,91 & 10,01 & $-0,414$ & 0,679 \\
& & Source: author's own research & & &
\end{tabular}

The opinions of students of other majors presented in Table 3 show that men more than women reported that their schools had provided extracurricular lectures on healthy lifestyles (Statement 2), provided leisure activities during lessons (Statement 5), teachers corrected students' body posture (Statement 7), and organized extracurricular activities and events promoting healthy lifestyles (Statement 11). These correlations were statistically significant (Table 3). 
Table 3. Opinions of students in other majors about the health education implementation in their schools.

\begin{tabular}{|c|c|c|c|c|c|c|}
\hline \multirow{2}{*}{$\begin{array}{l}\text { Implementation } \\
\text { of health educa- } \\
\text { tion content }\end{array}$} & \multicolumn{2}{|c|}{ Women, $\mathrm{n}=120$} & \multicolumn{2}{|c|}{ Men, $\mathrm{n}=39$} & \multicolumn{2}{|c|}{$\begin{array}{c}\text { Manna-Whitneya } \\
\text { U Test }\end{array}$} \\
\hline & M & SD & M & SD & Z & $\mathrm{p}$ \\
\hline Statement 1 & 2,18 & 1,29 & 2,21 & 1,30 & $-0,162$ & 0,871 \\
\hline Statement 2 & 1,55 & 1,05 & 2,08 & 1,33 & $-2,732$ & 0,006 \\
\hline Statement 3 & 1,25 & 0,69 & 1,46 & 0,88 & $-1,830$ & 0,067 \\
\hline Statement 4 & 2,99 & 1,26 & 2,72 & 1,32 & $-1,181$ & 0,238 \\
\hline Statement 5 & 1,65 & 1,07 & 2,21 & 1,45 & $-2,012$ & 0,044 \\
\hline Statement 6 & 3,07 & 1,45 & 3,18 & 1,43 & $-0,419$ & 0,675 \\
\hline Statement 7 & 1,72 & 1,04 & 2,44 & 1,27 & $-3,502$ & $<0,001$ \\
\hline Statement 8 & 3,86 & 1,13 & 3,92 & 1,16 & $-0,394$ & 0,693 \\
\hline Statement 9 & 2,27 & 1,26 & 2,56 & 1,35 & $-1,221$ & 0,222 \\
\hline Statement 10 & 2,73 & 1,34 & 2,95 & 1,34 & $-0,933$ & 0,351 \\
\hline Statement 11 & 2,73 & 1,36 & 3,23 & 1,44 & $-1,952$ & 0,050 \\
\hline Statement 12 & 3,02 & 1,30 & 2,82 & 1,55 & $-0,869$ & 0,385 \\
\hline Total & 28,99 & 8,84 & 31,77 & 11,50 & $-1,034$ & 0,301 \\
\hline
\end{tabular}

The analysis of the ways in which health education was implemented according to the physical education teacher's sex revealed no significant statistical differences. When dividing the respondents according to their major, there were also no differences with regard to the PE teacher's sex. As far as the physical education students were concerned, there were no respondents who declared that they were taught by both women and men (Tables 4-6). 
Table 4. Opinions of all surveyed students on the implementation of health education content depending on the PE teacher's sex.

Płeć nauczyciela WF

Manna-

\begin{tabular}{|c|c|c|c|c|c|c|c|c|}
\hline \multirow[t]{2}{*}{$\begin{array}{l}\text { Implementation of } \\
\text { health education } \\
\text { content }\end{array}$} & \multicolumn{2}{|c|}{$\begin{array}{c}\text { Women and } \\
\text { men } n=86\end{array}$} & \multicolumn{2}{|c|}{ Women, $n=140$} & \multicolumn{2}{|c|}{ Men, $\mathrm{n}=77$} & \multicolumn{2}{|c|}{$\begin{array}{c}\text { Whitneya U } \\
\text { Test }\end{array}$} \\
\hline & M & $\mathrm{SD}$ & M & $\mathrm{SD}$ & M & $\mathrm{SD}$ & $\mathrm{H}$ & $\mathrm{p}$ \\
\hline Statement 1 & 2,21 & 1,29 & 2,21 & 1,30 & 2,12 & 1,32 & 0,437 & 0,804 \\
\hline Statement 2 & 1,57 & 1,07 & 1,84 & 1,19 & 1,87 & 1,17 & 5,019 & 0,081 \\
\hline Statement 3 & 1,20 & 0,53 & 1,36 & 0,88 & 1,38 & 0,86 & 1,167 & 0,558 \\
\hline Statement 4 & 3,08 & 1,24 & 2,91 & 1,34 & 2,94 & 1,23 & 1,051 & 0,591 \\
\hline Statement 5 & 1,63 & 1,06 & 1,94 & 1,36 & 1,65 & 1,05 & 2,606 & 0,272 \\
\hline Statement 6 & 2,97 & 1,47 & 3,34 & 1,39 & 3,42 & 1,34 & 4,743 & 0,093 \\
\hline Statement 7 & 1,86 & 1,12 & 2,01 & 1,25 & 1,90 & 1,11 & 0,491 & 0,782 \\
\hline Statement 8 & 3,87 & 1,13 & 3,93 & 1,07 & 3,92 & 1,05 & 0,081 & 0,960 \\
\hline Statement 9 & 2,31 & 1,30 & 2,44 & 1,24 & 2,65 & 1,12 & 4,799 & 0,091 \\
\hline Statement 10 & 2,69 & 1,42 & 2,84 & 1,29 & 2,78 & 1,30 & 1,071 & 0,585 \\
\hline Statement 11 & 2,90 & 1,36 & 2,78 & 1,42 & 2,74 & 1,28 & 0,658 & 0,720 \\
\hline Statement 12 & 2,97 & 1,35 & 3,00 & 1,34 & 2,87 & 1,36 & 0,502 & 0,778 \\
\hline Total & 29,24 & 9,18 & 30,60 & 9,98 & 30,22 & 9,53 & 0,567 & 0,753 \\
\hline
\end{tabular}

Source: author's own research 
Table 5. Opinions of students of physical education on the implementation of health education content depending on the PE teacher's sex.

\begin{tabular}{|c|c|c|c|c|c|c|}
\hline \multirow{3}{*}{$\begin{array}{l}\text { Implementation of } \\
\text { health education } \\
\text { content }\end{array}$} & \multicolumn{4}{|c|}{ Teacher's gender } & \multirow{2}{*}{\multicolumn{2}{|c|}{$\begin{array}{c}\text { Manna- } \\
\text { Whitneya U } \\
\text { Test }\end{array}$}} \\
\hline & \multicolumn{2}{|c|}{ Women, $n=69$} & \multicolumn{2}{|c|}{ Men, $n=75$} & & \\
\hline & M & SD & M & SD & Z & $\mathrm{p}$ \\
\hline Statement 1 & 2,33 & 1,31 & 2,07 & 1,30 & $-1,285$ & 0,199 \\
\hline Statement 2 & 1,90 & 1,18 & 1,85 & 1,16 & $-0,015$ & 0,988 \\
\hline Statement 3 & 1,32 & 0,83 & 1,36 & 0,85 & $-0,257$ & 0,797 \\
\hline Statement 4 & 3,13 & 1,36 & 2,91 & 1,23 & $-1,062$ & 0,288 \\
\hline Statement 5 & 1,91 & 1,41 & 1,63 & 1,02 & $-0,704$ & 0,482 \\
\hline Statement 6 & 3,46 & 1,37 & 3,39 & 1,35 & $-0,394$ & 0,693 \\
\hline Statement 7 & 2,13 & 1,33 & 1,87 & 1,10 & $-1,024$ & 0,306 \\
\hline Statement 8 & 4,01 & 0,99 & 3,89 & 1,05 & $-0,659$ & 0,510 \\
\hline Statement 9 & 2,55 & 1,23 & 2,61 & 1,10 & $-0,550$ & 0,582 \\
\hline Statement 10 & 2,83 & 1,36 & 2,73 & 1,29 & $-0,380$ & 0,704 \\
\hline Statement 11 & 2,81 & 1,43 & 2,69 & 1,26 & $-0,424$ & 0,672 \\
\hline Statement 12 & 3,06 & 1,31 & 2,84 & 1,36 & $-1,003$ & 0,316 \\
\hline Total & 31,45 & 10,01 & 29,84 & 9,36 & $-0,674$ & 0,500 \\
\hline
\end{tabular}


Table 6. Opinions of students of other majors on the implementation of health education content depending on the PE teacher's sex.

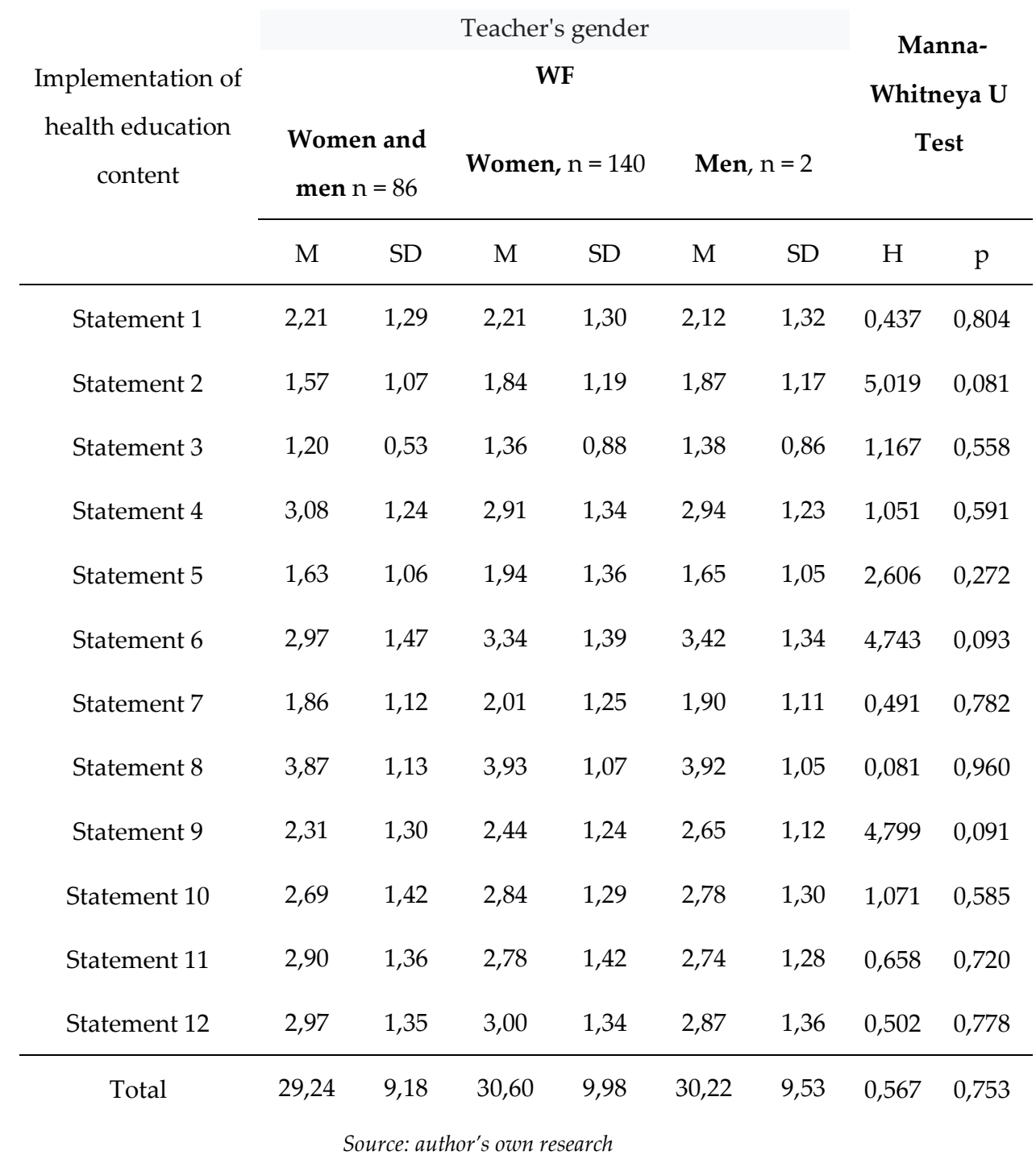

Figures 1-7 present opinions of students of various majors on the forms of implementation of health education at school. The mean scores of individual statements, ranging from 1-2 points, indicate that lectures for students outside their physical education classes, lectures for parents, active recreation during classes, and correcting students' body posture had been very rarely conducted (Figures 1-4). Slightly more frequent were lectures given by invited speakers from outside the school, e.g. doctors, nutritionists, nurses (Figure 5), and organization of extracurricular activities and health-promoting events (Figure 6). The total of all opinions on the questionnaire questions is between 29.50 and 31.77 out of a possible 60 points. Women's declarations were at a lower level than men's, but they did not differ significantly. 


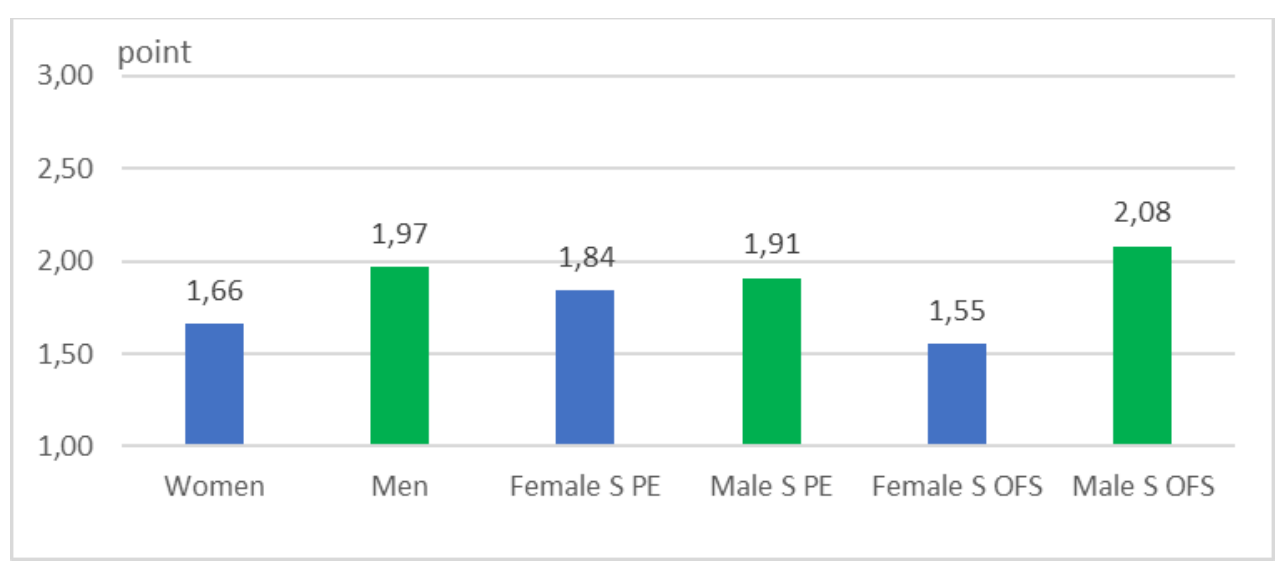

Legende: S PE students of physical education, S OFS students other fields of study

Figure 1. Comparison of opinions of students of different majors on teachers' lectures outside physical education classes (Source: author's own research).

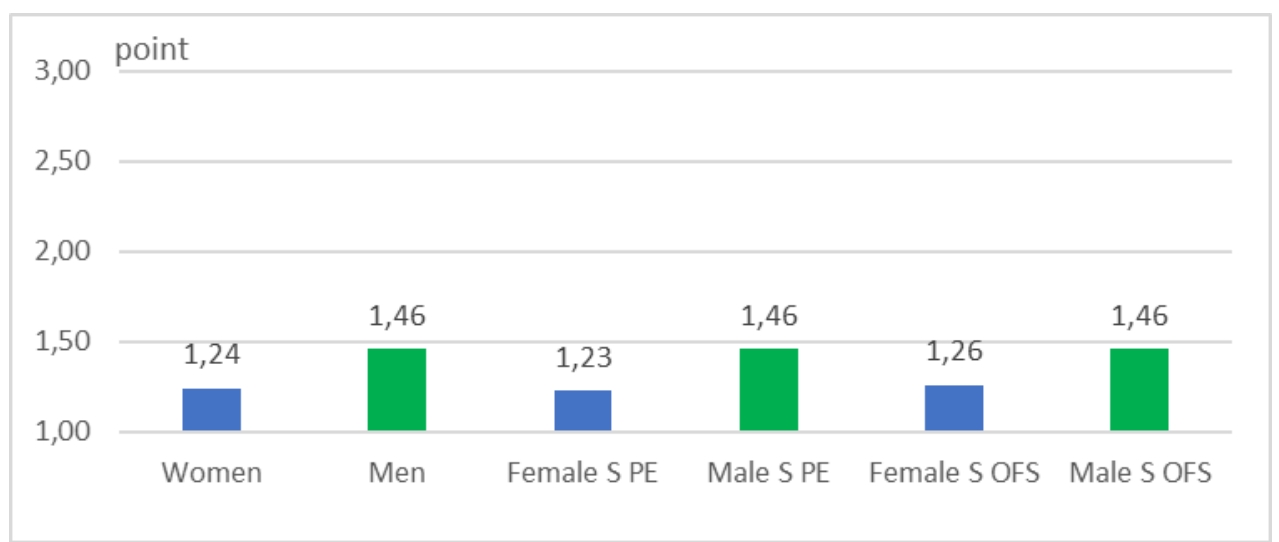

Figure 2. Comparison of opinions of students of different majors on lectures for parents (Source: author's own research).

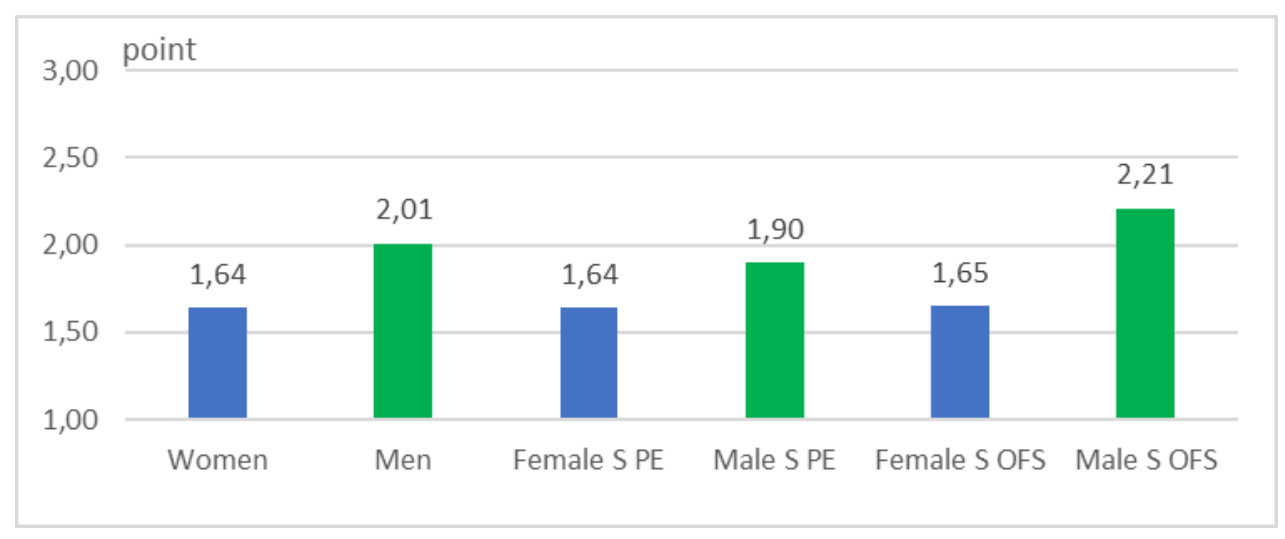

Figure 3. Comparison of opinions of students of different majors on the provision of active recreation during classes conducted by other teachers (Source: author's own research). 
Figure 4. Comparison of opinions of students of diff

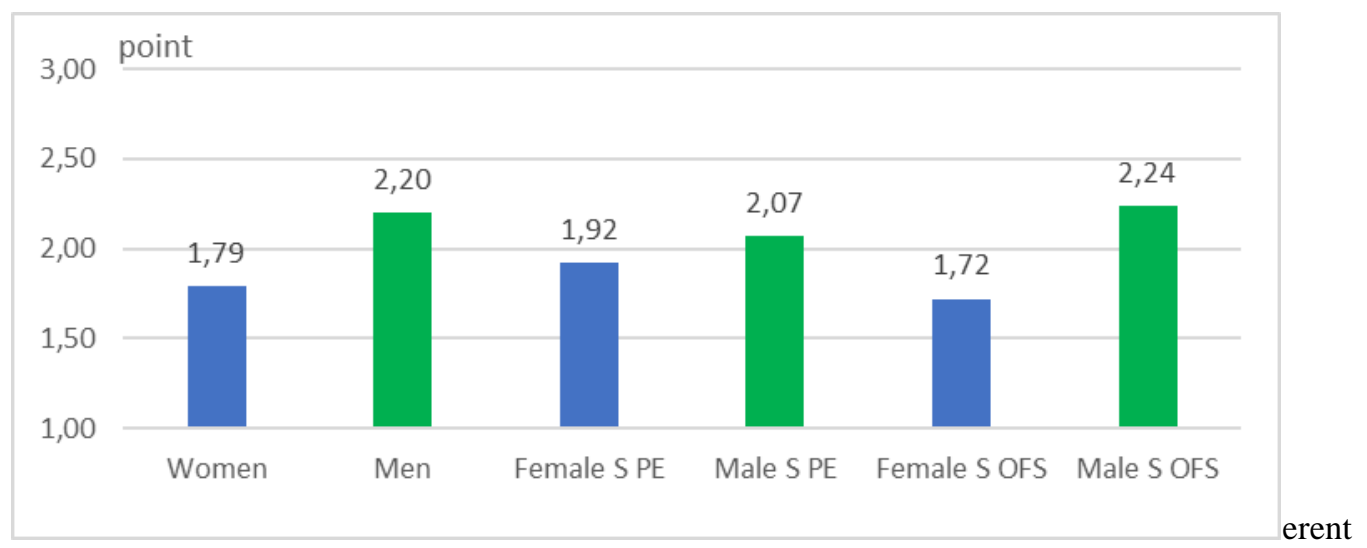

majors on correcting students' body posture(Source: author's own research).

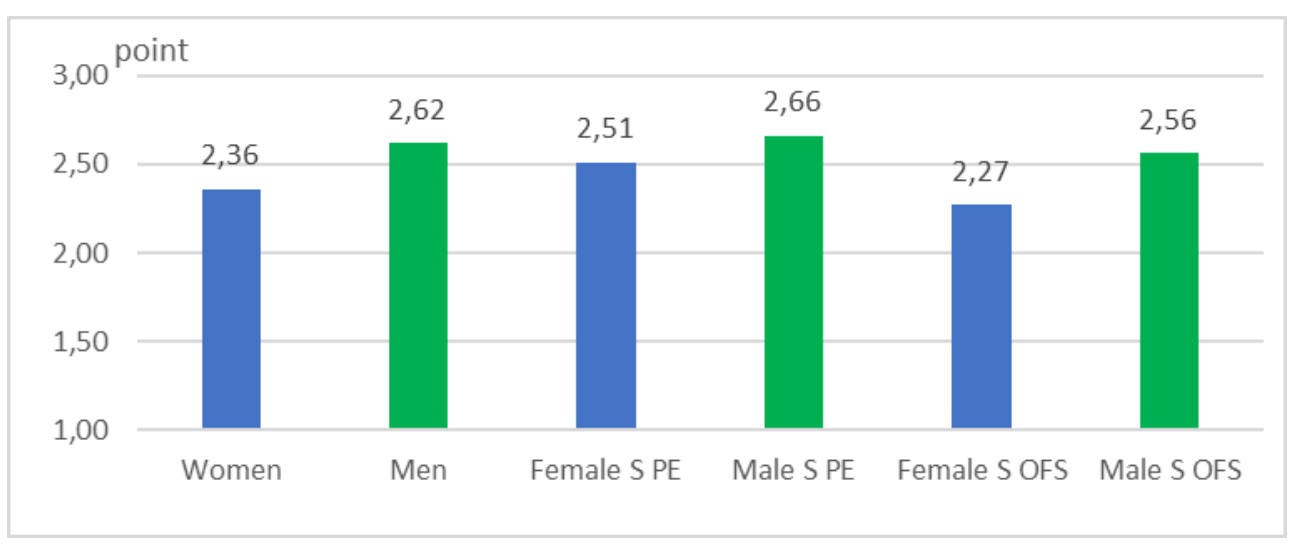

Figure 5. Comparison of opinions of graduate students on lectures given by experts outside school and application of healthy lifestyle principles at school (Source: author's own research).

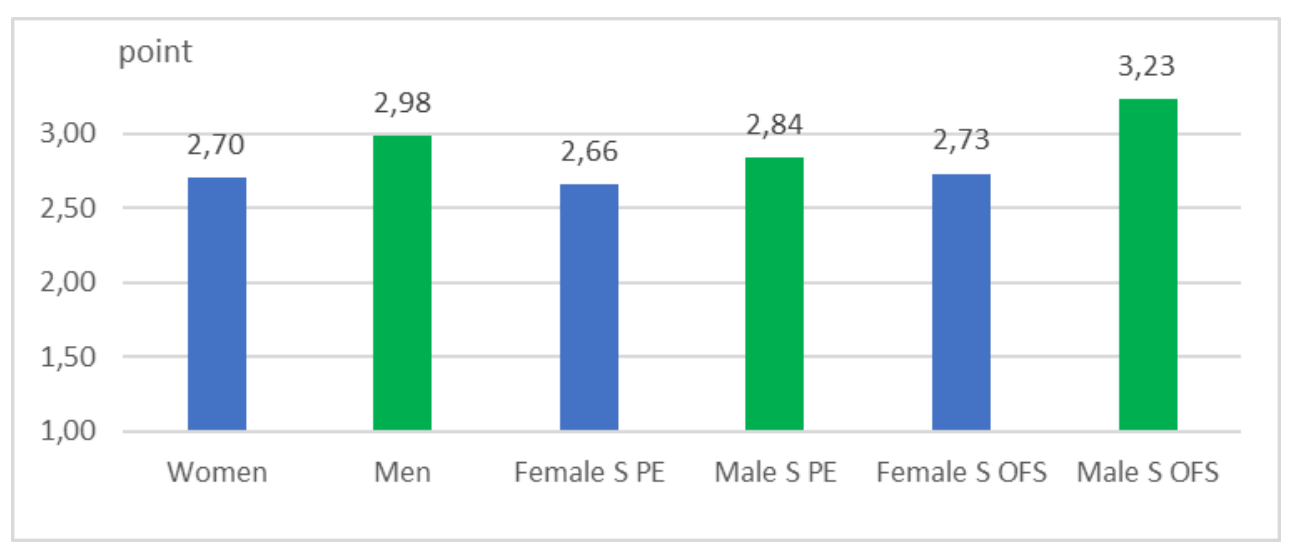

Figure 6. Comparison of opinions of students from different majors on the organization of extracurricular activities and health-promoting events (Source: author's own research). 


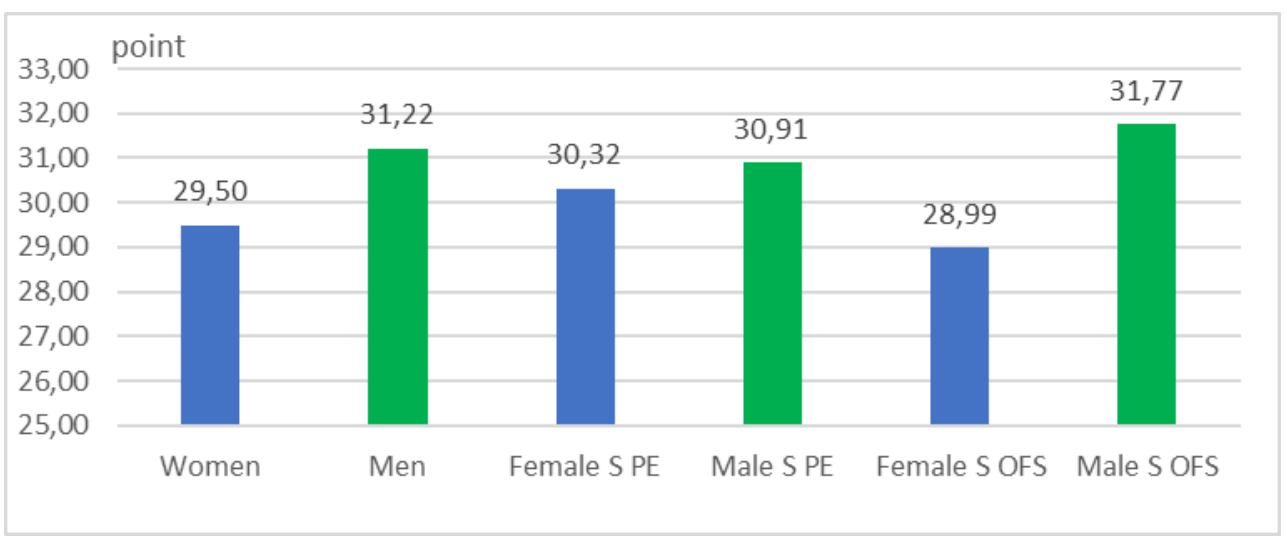

Figure 7. Comparison of opinions of students of different majors on the implementation of healthrelated educational content (aggregate) (Source: author's own research).

\section{Discussion}

K. Górna-Łukasik and K. Skalik in their research on university students from Katowice, found that sports and recreational events for students, teachers and parents, had been the most common form of implementation of health education, followed by extracurricular activities and other events organized jointly by teachers of physical education and other subjects, and then by competitions and exhibitions on health issues (Górna, Skalik 2021). The situation was similar in the study of Szczecin students. In the opinions of students from Katowice, lectures for parents and lectures delivered by outside experts had been the least frequently implemented forms of health education [41]. The results were similar among the Szczecin students. Posture correction and organization of active recreation during lessons were rare in both studied school environments.

The majority of respondents negatively assessed the application of healthy lifestyle principles at school [41], both in the Katowice and Szczecin studies. Thus, the findings of the Polish Supreme Audit Office critically assessing this component of school functioning can be corroborated [42].

The effects of implemented health education depend not only on the actions taken by PE teachers, who, as previously mentioned, have been assigned the role of health leaders in the education system. Their organizational skills, knowledge, teaching preparation, and 'pedagogical talent' are certainly half of the success. Nevertheless, many teachers claim that they are not fully prepared to implement health education, especially in terms of using activating methods and conducting theoretical classes, and that their hindered access to resources and teaching aids intensify their reluctance to implement health education content in the educational process [1,43]. Different barriers often arise in the cooperation of so many factors, which makes it difficult to achieve the desired results of 'health science'. In addition to the barriers on the part of the teacher, the financial limitations of educational institutions, lack of training offers for teachers, undervaluation by school principals and representatives of leading bodies of the importance of health education in preparing students for adult life, reluctance of teachers of other subjects to cooperate in the implementation of pro-health tasks, lack of involvement of parents in the life of the school, and thus in the process of health education of their children, as well as time and space limitations should also be indicated. One more important determinant of the effectiveness of health education is the interest and involvement of students themselves.

\section{Conclusions}

Perhaps it is thanks to health education - properly implemented, aimed mainly at raising awareness and involvement, allowing students to co-organize the educational space and select content - that attendance at physical education classes will increase, and thus the goals of health education will be achieved. The study results deomonstrate a low 
degree of implementation of these educational contents. The Polish school offers students few forms of preparation for taking care of their own health. Opinions of students from Szczecin's universities confirm some serious neglect in this area of education. Therefore, it can be assumed that school teachers are insufficiently prepared to fulfil the role of health educators. Their theoretical knowledge does not translate into the development of appropriate attitudes of their students towards the care for their own and others' health.

Author Contributions: Conceptualization, D.U.; methodology, D.U. and L.P-K.; validation, D.U. and L.P-K.; formal analysis, D.U.; investigation, D.U. and L.P-K.; resources, D.U. and L.P-K.; data curation, D.U. and L.P-K.; writing - original draft preparation, D.U.; writing - review and editing, D.U.; visualization, D.U.; supervision, D.U.; project administration, D.U.; funding acquisition, D.U. All authors have read and agreed to the published version of the manuscript.

Funding: This research received no external funding.

Informed Consent Statement Informed consent was obtained from all subjects involved in the study.

Data Availability Statement: The data is available upon request to corresponding author's email.

Conflicts of Interest; The authors declare no conflict of interest.

\section{References}

1. Woynarowska, B. Health education. Academic textbook; Polish Scientific Publishers PWN: Warsaw, Poland, 2010.

2. Sęk, H.; Cieślak, R. Social support, stress and health. Polish Scientific Publishers PWN: Warsaw, Poland, 2012.

3. Żuchelkowska, K. Health education in kindergarten. Kazimierz Wielki University Press: Bydgoszcz, Poland, 2013.

4. Nutbeam, D.; Levin-Zamir, D.; Rowlands, G. Health Literacy in Context. Int. J. Environ. Res. Public Health 2018, 15, 2657, doi:10.3390/ijerph15122657.

5. Popławska, A.; Jacewicz, A. Activities for the development of children's health competences and their effectiveness. Pre-school and Early School Pedagogy 2019, 7, 1 (13), $25-41$.

6. Wolny, B. Health education at school. A guide for school principals and teachers. Education Development Center: Warsaw, Poland, 2019.

7. Sentell, T.; Vamos, S.; Okan, O. Interdisciplinary Perspectives on Health Literacy Research Around the World: More Important Than Ever in a Time of COVID-19. Int. J. Environ. Res. Public Health 2020, 17, 3010, doi:10.3390/ijerph17093010.

8. Han, M.K. Public Health Science; Hyungseul Press: Gyeonggi, Korea, 2003.

9. Obodyńska, E. The concept of health education and health promotion at school - the genesis and purposefulness of its implementation. Education - Technology Informatics 2016, 4/18, 57-63.

10. Bulska, J. Health education and health promotion at the Health Promoting School activities for cooperation with the local community. HUMANUM Institute of International Studies and Education 2017, 25(2), 155-162.

11. Kędzior, M. Contemporary health education at the early school level. In: Contemporary research in pedagogy. Theory - research - practice in the area of preschool 
and early childhood education, care and educational pedagogy, pedagogical therapy and broadly understood educational sciences vol. 47 (1), Żmichrowska, M. J. ed., Publishing House of the Higher School of Management and Entrepreneurship based in Wałbrzych, Wałbrzych, 2019, 255-270.

12. Szpak, M. Shaping the sense of physical and mental security of students in the implementation of health education assumptions during physical education classes. Scientific Journals of Civilization Approach 2020, XVI(2), 28-53.

13. Regulation of the Minister of National Education of 30 January 2018 on the core curriculum for comprehensive secondary schools, technical high schools and secondary vocational schools. Journal of Laws 2018, item 467.

14. Hallal, P.; Andersen, L.; Bull, F; Guthold, R.; Haskell, W.; Eklund, U. Global physical activity levels: surveillance progress, pitfalls, and prospects. The Lancet 2012, 380, 147-157.

15. Condello, G.; Capranica, L.; Stager, J.; Forte, R.; Falbo, S.; Di Baldassarre, A.; SeguraGarcia, C.; Pesce, C. Physical activity and health perception in aging: Do body mass and satisfaction matter? A three-path mediated link. PLoS ONE 2016, 11(9), doi:10.1371/journal.pone.0160805.

16. Curi, V.S.; Vilaça, J.; Haas, A.N.; Fernandes, H.M. Effects of 16-weeks of Pilates on health perception and sleep quality among elderly women. Arch. Gerontol. Geriatr. 2018, 74, 118-122, doi: 10.1016/j.archger.2017.10.012.

17. Regulation of the Minister of National Education of February 14, 2017 on the core curriculum for pre-school education and the core curriculum for general education for primary schools, including students with moderate or severe intellectual disability, general education for the first-cycle industry school, general education for special education training for work and general education for post-secondary schools. Journal of Laws 2017, item 356.

18. Woynarowska, B. Features of modern health education. In: Organization and implementation of health education at school. A guide for school principals and teachers, Woynarowska, B. ed., Education Development Center, Warsaw, 2011, 13-18.

19. Schulte-Körne, G. Mental health problems in a school setting in children and adolescents. Deutsche Arzteblatt International 2016, 113(11), 183-190, doi: 10.3238/arztebl.2016.0183.

20. Rogacka, A. Health education in the core curriculum. Secondary school. Technical school. Booklet 3. Education Development Center, Warsaw, 2019.

21. Tuszyńska, L. The impact of health education on the lifestyle of upper secondary school students. Yearbook of Świętokrzyski, Series B - Natural Sciences 2012, 33, 121138.

22. Kostencka, A. Health education - expectations, priorities, tips. In: Health education in physical education. Implementation of the core curriculum. Kostencka, A .; Śmiglewska, M.; Szark-Eckardt, M. ed., Mirosław Wrocławski Publishing House, Bydgoszcz,2012, 11-48. 
23. Świtała, S.; Gnitecka, J.; Supiński, J. Desirable qualities of a physical education teacher in the eyes of students and their parents. Scientific Annals of the University of Physical Education and Tourism in Białystok 2016, 1(15), 5-14.

24. Ostrowska, M. Health education as a concept of upbringing in contemporary school. In: Person - education, physical activity, health. Kostenck, A .; Żukowska, H .; SzarkEckardt, M .; Musket, R .; Bendíková, E. ed., Mirosław Wrocławski Publishing House, Bydgoszcz, 2014, 68-80.

25. Linca-Ćwikła, A. Influence of educational environments on shaping health behaviors of adolescents. In: Care and educational activity in the face of contemporary challenges. Łuczyński, A .; Gumińska-Sagan, 1st ed., Publishing House of the Catholic University of Lublin, Lublin, 2016, 297-313.

26. Rasmus, P.; Stetkiewicz-Lewandowicz, A.; Talarowska, M.; Sobów, T. Health education from the perspective of contemporary challenges and threats. Polish Merkuriusz Lekarski 2013, XXXIV, 204, 363-367.

27. Czechowski, M.; Żukowska, Z. Competences of physical education teachers to implement health education. Annals of the National Institute of Hygiene 2010, 61, 4, 395-399.

28. Wojciechowska, K. Teacher - a guide in the process of promoting health at school. Pedagogical Annals 2014, 6(42), 2, 127-141.

29. Olejniczak-Nowakowska, M. Addressees of activities in the field of health education. In: Health promotion and health education with elements of pedagogy. WoźniakHolecka, J .; Braczkowski, R. S. ed., Medical University of Katowice, Katowice, 2014, 91 103.

30. Wrona-Wolny, W.; Makowska, B. Opinions of students - future physical education teachers on the health education classes they carry out at school. Hygeia Public Health. 2011, 46, 4, 477-483.

31. Borzucka-Sitkiewicz, K. Implementation of the concept of the Health Promoting School in Poland. Report on research carried out in schools with the national certificate of Health Promoting Schools. CHOWANNA 2016, 2(47), 251-268.

32. Łomińska, K. he scope of health education in the fourth stage of school education. ePublishing House of the National Center for Physical Condition Research, 2014, 39-45.

33. Nowak, P. F. Implementation of health education at school in the opinions of teachers. General Medicine and Health Sciences 2012, 18, 3, 171-175.

34. Zadarko-Domaradzka, M. Implementation of health education in schools in Podkarpacie after the curriculum reform in the opinion of physical education teachers. Scientific Dissertations of the Academy of Physical Education in Wrocław 2015, 48, 119-126.

35. Truszkiewicz, A.; Olejniczak, D.; Religioni, U.; Skonieczna, J. Health education in the school environment - surveying the opinions and expectations of middle and high school students. General Medicine and Health Sciences 2015, 21, 1, 24-28.

36. Charzyńska-Gula, M.; Jaworska, M.; Bogusz, R.; Kocka, K.; Domżał-Drzewicka, R.; Wasil, A. Implementation of health education in primary, middle and high schools in the light of the opinion of a selected group of students. General Medicine and Health Sciences 2013, 19, 4, 431-438. 
37. Kap, K., Skowronek; E., Sarnecka, J. The role of school in shaping a healthy lifestyle of students on the example of the opinion of high school students. Publishing house of the Maria Curie-Skłodowska University, Annales Universitatis Mariae Curie-Sklodowska 2017, 72, 2, sectio B, 163-178.

38. Szkudlarek, A.; Kaźmierczak, A.; Kowalska, J. E. The role and place of health education in the curricula of high schools in Lodz. In: Pedagogical dimension of physical and health culture in the life of modern man. Kaźmierczak, A .; Kowalska, J.E .; MaszorekSzymala, A .; Makarczuk, A. ed., Publishing House of the University of Lodz, Łódź, 2016, 169-183.

39. Świtała, S.; Bukowska, KHealth education in the opinion of the students of High School No. 10 in Wrocław. Scientific Annals of the University of Physical Education and Tourism in Białystok 2016, 2, 16, 35-44.

40. Górna-Łukasik, K. Questionnaire for the evaluation of the implementation of physical education in secondary school, construction and methodological verification. Physical Activity of People of Different Ages 2017, (33-36), 1-4, 7-18.

41. Górna-Łukasik, K.; Skalik, K.. Education for a healthy lifestyle in high school in the opinions of students. Whole school integration. In: Contemporary problems of physical education, part 4, Polechoński, J .; Skalik, K. ed., Publishing House of the Academy of Physical Education, Katowice, 2021, 9-26.

42. Zaleski-Ejgierd, A. Physical education in schools - methods of health education. State Control 2014, 59, 5(358), 39-54.

43. Gaweł, A. School and teacher in the face of contemporary challenges of promoting the health of children and youth. Lublin Pedagogical Yearbook 2016, XXXV, 3, 137-152. 1. 